\title{
Anetta ZIELIŃSKA
}

\section{THE LEVEL OF REVERSE LOGISTICS}

IMPLEMENTATION IN TERMS OF WASTE

MANAGEMENT IN POLISH VOIVODSHIPS

ACCORDING TO A MULTIVARIATE

COMPARATIVE ANALYSIS

Anetta Zielińska, Prof. (ORCID: 0000-0001-8592-3530) - Wroclaw University of Economics and Business

Correspondence address:

Komandorska Street 118/120, 53-345 Wroclaw, Poland

e-mail: anetta.zielinska@ue.wroc.pl

ABSTRACT: In practice, reverse logistics in Poland refers to a narrow approach within the framework of the waste management problem. The voivodships have been obliged to implement reverse logistics processes more effectively through waste management. The article aims to diagnose the implementation level of waste management processes (part of reverse logistics) in Polish voivodships. The research used a multivariate comparative analysis that ranks voivodships according to waste management indicators. The research will result in preparing the ranking of voivodships listing the leaders and those unsuccessful in the implementation of waste management. Based on the research, Śląskie and Podlaskie voivodships were selected as the ones presenting the highest level of waste management implementation, whereas the lowest level was recorded for Lubuskie voivodship.

KEYWORDS: waste management, recycling, reverse logistics, multivariate comparative analysis 


\section{Introduction}

Reverse logistics represents a current research area in theoretical and empirical terms. In Poland, reverse logistics refers to a narrow approach within the framework of the waste management problem in practice. Increasingly stringent national and transnational measures and regulations regarding waste and waste management are coming to the fore.

In the system of reverse logistics, the direction of activities takes place from the consumer towards the producer, through the implementation of such processes as (see de Brito, Dekker, 2003, p. 3-27; Wadhwa, et al., 2009, p. 462; Zielińska, et al., 2016, pp. 207-214):

- repairs and reuse - the re-introduction of an unchanged product to the system, while its quality cannot be lower than that of a new product,

- renovation (rejuvenation) - ensuring the appropriate quality of returns by dismantling, control and exchange of faulty elements, and also by technological modernisation, i.e. the replacement of old modules and components with the technologically better and more advanced ones,

- regeneration - bringing the appropriate quality required from new goods to the used goods by a total disassembly, detailed repair and the exchange of outdated parts,

- cannibalisation - recovering a relatively small number of parts and modules from the used product and subjecting them to the process of repair, renovation or regeneration,

- recycling - reprocessing the materials contained in returns during the production process to obtain material to be used along with its original purpose or with another one.

Since the end of the 20th century, the importance of reverse logistics has grown for several reasons:

- the amount of product returns can be very high, with some industries experiencing returns at over $50 \%$ of sales (Trebilcock, 2002, p. 31-45),

- end-of-life take-back laws have proliferated over the past decade in the European Union, requiring businesses to effectively manage the entire life of the product (Fishbein, 1994),

- landfill capacity has become limited and expensive. Alternatives such as repackaging, remanufacturing and recycling have become more prevalent and diable (Thierry et al., 1995, pp. 114-134).

Improving the recycling and remanufacturing rate of end-of-life products is necessary to reduce the negative impact of harmful substances on the environment and promote recycling and sustainable development. Recycling and remanufacturing activities carried out by enterprises are combined with 
their traditional positive supply chain to form a closed-loop supply chain system (Daniel et al., 2009).

Approaching reverse logistics in terms of waste management requires clarification. Waste management in accordance with the Waste Management Act is "the collection, transport, processing of waste, including the supervision over such activities, as well as the subsequent handling of waste disposal sites and the activities performed as a waste seller or waste management intermediary" (Act of December 14, 2012, (3) section 1 point 2).

In Poland, public administration units, including voivodships, have been obliged to implement the processes of reverse logistics processes more effectively through waste management. Hence, voivodship authorities (voivodship parliaments) should undertake all possible measures to reduce the amount of generated waste. There is an urgent need to change the traditional approach of voivodship parliaments to waste management; they should be focused on reverse logistics activities, primarily the recycling processes. Nowadays, reverse logistics represents a remarkable part of logistics processes carried out by enterprises, which should be supervised and controlled, and the voivodship authorities should perform these tasks.

The article aims to diagnose the level of implementing waste management processes (as part of reverse logistics) in Polish voivodships. A multivariate comparative analysis was used in the research, based on the indicators describing waste management for voivodships (data provided by Statistics Poland). The research will result in preparing the ranking of voivodships listing the leaders and those unsuccessful in implementing waste management.

\section{Literature review}

Scientists started defining reverse logistics as early as the 1970s (Guiltinan et Nwokoye, 1975, Ginter et Starling, 1978). However, they paid attention to returns did not refer to them as the reverse flow logistics. According to Lambert, Stock, Ellram: "reverse logistics deals with the removal of waste material, which originates in the process of production, distribution and wrapping of goods. Typically, it is the activity such as securing temporary storage of these materials, their subsequent removal from the disposal site, processing, reuse or recycling" (Lambert et al., 2000). However, reverse logistics begins, where classic logistics end, it is associated with the creation of added value in the reverse direction in relation to the primary flow in logistics processes (Grant et al., 2017). Reverse logistics is defined as: "the process of planning, implementing, and controlling the efficient, cost-effective flow of raw materials, in-process inventory, finished goods and related information 
from the point of consumption to the point of origin to recapture value or proper disposal" (Rogers, Tibben-Lembke, 1998). However, K. Hawks claims that it is "the process of moving goods from their typical final destination to capture value or proper disposal. Remanufacturing and refurbishing activities may also be included in the definition of reverse logistics" (Hawks, 2006). Finally, according to the American Reverse Logistics Executive Council, reverse logistics is a series of activities required to retrieve a product from a customer and either dispose of it or recover its value (Rogers, Tibben-Lembke, 2001, pp. 129-148).

The introduction indicated that Polish source literature approaches reverse logistics as waste and packaging management. According to J. Szołtysek "reverse logistics refers to all processes managing the flow of waste (including defected goods) and information (connected with these flows) from the place of their origin to the place of their destination in order to recover their value (through repair, recycling or processing) or an appropriate treatment and long-term storage so that such flows are economically effective and minimise negative influence of waste on the environment" (Szołtysek, 2009, p. 80). A. Mesjasz-Lech has a slightly different approach to reverse logistics since the main goal of reverse logistics through waste management is the size of waste flow in cities. The concept of a zero-waste city requires the activities of reverse logistics, as it is not possible to reduce municipal waste without the proper organisation of waste flows and infrastructure - reverse logistics function (Mesjasz-Lech, 2020, pp. 320-332). The author indicates the role to be played by public administration units in the flow of reverse logistics chain (e.g. voivodships).

\section{Legislation regulating waste management at the voivodship level}

Polish legislation on waste management in relation to the public administration unit, i.e. a voivodship, is based on the following documents:

- Act of December 14, 2012, on Waste (Journal of Laws 2021, item 779).

- Act of September 13, 1996, on Maintaining Cleanliness and Order in Municipalities (Journal of Laws 2021, item 888).

- Resolution No. 88 of the Council of Ministers of July 1, 2016, on the National Waste Management Plan 2022 (Monitor Polski 2016, item 784).

- Regulation of the Minister of the Environment of July 1, 2015 on the method and form of drawing up a voivodship waste management plan and an investment plan template (Journal of Laws 2015, item 1016). 
It should be noted that Polish legislation has to be compatible with the provisions of the European Union law, in particular, the "Waste package" consisting of four directives:

- $\quad$ EU, 2018. Directive 2008/98/EC on waste, L. 851.

- $\quad$ EU, 2018. Directive 94/62/EC on packaging and packaging waste, L. 852.

- EU, 2018. Directive 1999/31/EC on the landfill of waste, L. 850.

- EU, 2018. Directive 2000/53/EC on end-of-life vehicles, 2006/66/EC on batteries and accumulators and waste batteries and accumulators, and 2012/19/EU on waste electrical and electronic equipment, L. 849.

In recent years, Polish and EU legal regulations regarding waste management have been subject to ongoing modifications.

In Poland, in the Ministry of Climate and Environment, the problem of waste management remains within the responsibility of the Waste Management Department, which prepares, e.g., guidelines for drawing up voivodship waste management plans in terms of municipal waste and for preparing reports on the implementation of voivodship waste management plans.

The voivodship self-government (Voivodship Marshal's) performs the following tasks regarding waste management (Act of December 14, 2012):

1. Issues the decision approving the reclassification of hazardous waste into non-hazardous waste, or a decision of expressing an objection (Article 8 (5)).

2. Allows, by way of a decision, if, for the reasons of safety or in order to ensure the continuity of collecting infectious medical waste or infectious veterinary waste, it is required to collect this waste (Article 23 (4)).

3. Allows, by way of a decision, if the incineration of waste in installations or devices designed for this purpose is impossible for safety reasons, for the incineration of waste outside the installations or devices (Article 31 (1)).

4. Allows waste processing for projects that may always have a significant impact on the environment; processing for non-hazardous waste subject to recovery in the recovery process based on filling in the unfavourably transformed areas; processing for municipal installations (Article 41 (3)).

5. Issues decisions on approving instructions for operating a waste landfill, extracting waste, closing a waste landfill or its separate part, or a decision of expressing an objection (Articles 129-135, 144, 146, 148, 151).

6. Maintains a database on products and packaging as well as waste management (BDO Register - Product, Packaging and Waste Management Database).

Waste management plans are developed at the national and voivodship level. Voivodship waste management plans include (Act of December 14, 2012, Articles 34-35):

1. Waste management plans. 
2. Forecasted changes in waste management, including those resulting from demographic and economic changes.

3. The adopted waste management objectives, including deadlines for meeting them.

4. Identifying municipal installations in the voivodship area.

5. Schedule for shutting down installations that do not meet the environmental protection requirements, the modernisation of which is not possible for technical reasons or is not justified for economic reasons.

Voivodship waste management plans have to remain in line with the assumptions of the National Waste Management Plan.

The purpose of the voivodship plans is to balance the capacity of waste treatment installations and to diagnose the tasks required to ensure integrated waste management. In turn, voivodship self-governments play an important role in implementing and controlling the product, packaging and waste management database, which will improve the waste management reporting process and reverse logistics processes.

\section{Research methods}

The empirical research presented below aims to assess the level of waste management implementation (reverse logistics) in Polish voivodships. The research applies a multivariate comparative analysis (MCA) for voivodships using waste management indicators according to the data provided by Statistics Poland. The research will result in ranking voivodships from the highest to the lowest level of implementing waste management processes as reverse logistics processes.

Data variety used in comparative analyses to describe the phenomenon of waste management as an element of reverse logistics implies the need for using multiple measuring units presenting different values. Consequently, it makes it impossible to compare the situation in various areas or even in the same area characterised by the changing intensity of particular phenomena types. For this reason, such methods have to be searched for which allow procedure objectification aimed at the general assessment of waste management condition; therefore, the method of multivariate comparative analysis, in the form of linear ordering, can be applied in this case (Zeliaś, 1989; Pluta, 1986; Pociecha, et al., 1988). Linear ordering, using a synthetic development measure (SDM), allowed ranking objects (voivodships) "from the best to the worst" (Walesiak, 2006; Walesiak and Gatnar, 2009).

The problem under study, i.e. the level of waste management implementation in a voivodship, is a highly complex issue. The classified objects (voivodships) are described using many indicators, resulting in difficulties 
associated with assessing objects' similarity and thus their classification. The level of objects' similarity regarding one feature may be different from the similarity of the same objects in terms of another feature, thus the need to classify objects using formal procedures, allowing an objective analysis in the conditions of complexity characteristic for the waste management phenomenon (Zielińska, 2019, p. 341).

Unifying the nature of variables (indicators describing waste management) is the first step of a multivariate comparative analysis. Such unification is not conducted when all variables represent stimulants, i.e. affect the analysed collective phenomenon (the state of waste management) positively. If the set of indicators includes destimulants or nominants, it is required to convert them into stimulants ${ }^{1}$.

The conversion of destimulants $(D)$ into stimulants $(S)$ using the quotient transformation was applied in the article (Walesiak, 1993, pp. 38-40):

$$
S_{i j}=b\left[D_{i j}\right]^{-1}
$$

where:

$S_{i j}$ - value of j-th stimulant observed in i-th object (voivodship),

$D_{i j}$ - value of j-th destimulant observed in i-th object (voivodship),

$b$ - constant value adopted arbitrarily, in calculations $b=\min D_{i j}$

Removing values of the studied variables (waste management indicators) and unifying orders of magnitude to allow their comparability (so-called normalisation) is the next step in the process of multivariate comparative analysis (Walesiak, 1988, pp. 63-71). The following normalisation formula was used in this case (Jajuga, Walesiak, 2000, p. 109):

where:

$$
z_{i j}=\frac{x_{i j}-\bar{x}_{j}}{s_{j}}
$$

$Z_{i j}$ - normalized value of $\mathrm{j}$-th of a given waste management indicator in $\mathrm{i}$-th object

(voivodship),

$x_{j}$ - arithmetic mean of $j$-th of waste management indicator,

$S_{j}$ - standard deviation of j-th waste management indicator,

$x_{i j}$ - value of j-th waste management indicator observed in i-th object (voivodship).

1 Waste management is described by the set of variables which may include: stimulants, destimulants and nominants. Stimulants represent the variables of which higher numerical values imply the desired changes of a given phenomenon. Destimulants are the variables of which higher values indicate undesirable changes in the studied phenomenon. The nominant features are characterized by a certain level of saturation, any deviations from which imply negative changes in the analysed phenomenon (Pluta, 1986). 
The application of the normalisation formula to all waste management indicators was followed by developing a normalised data matrix (Z) used for further calculations (see Zielińska, Sej-Kolasa, 2004).

When the normalised data matrix is determined, the hierarchical classification applies the methods of linear ordering for the set of objects (voivodships). According to the adopted criterion, the aforementioned methods are applied to rank (order) objects or their sets. These methods can be applied only if a certain overriding criterion is adopted, following which it is possible to rank the objects from the "best" to the "worst". Synthetic development measure (SDM) is the tool in linear ordering methods, which is the function aggregating partial information included in individual indicators and is designated for each object from the sets of objects. In general terms, the aggregation formulas for indicator values can be divided into the model and nonmodel ones (for more see: Gatnar and Walesiak, 2004, pp. 351-355; Grabiński, 1984, p. 38).

The calculations were based on a non-model formula, where pi takes the mean normalised value of waste management indicators for an individual voivodship. The "best" country is the one taking max pi value, whereas the "worst" - min pi (see Zielińska, et Sej-Kolasa, 2004):

$$
P_{i}=\frac{1}{m} \sum_{j=1}^{m} z_{i j}
$$

where:

$P_{i}$ - synthetic development measure for i - th object (voivodship),

$m$ - number of data describing waste management indicators,

$z_{i j}$ - normalised value of $\mathrm{j}$-th of a given waste management indicator in $\mathrm{i}$-th object (voivodeship).

Not all waste management indicators were assigned ranks in the study because there is no information in the source literature or the conducted research that would describe the analysed indicators' role in assessing the implementation of reverse logistics (Zielińska, 2020, p.177). 


\section{Results of the research}

The conducted analysis applied a multivariate comparative analysis using the possible to determine waste management indicators as part of reverse logistics for voivodships. The indicators were retrieved from the Statistics Poland database for 2019. As a result, 12 waste management indicators were selected to describe voivodships, as presented in table 1:

1. Mass of municipal waste generated per capita [kg].

2. Share of recycled waste compared to total waste generated per year (excluding municipal waste) [\%].

3. Share of recovered waste compared to total waste generated per year (excluding municipal waste) [\%].

4. Share of waste subject to neutralisation compared to total waste generated per year (excluding municipal waste) [\%].

5. Share of municipal waste collected selectively from households compared to total waste [\%].

6. Indicator of enterprises collecting mixed municipal waste [\%].

7. Cost-effectiveness indicator of services for the collected municipal waste $[\mathrm{PLN} / \mathrm{t}]$.

8. Mixed municipal waste collected per capita per year [kg].

9. Share of waste deposited in landfills as mixed municipal waste [\%].

10. Share of revenues from waste management fees compared to revenues for the National Fund for Environmental Protection and Water Management [\%].

11. Landfill capacity per capita $\left[\mathrm{m}^{3}\right]$.

12. Expenditure on fixed assets for recycling and the use of waste per capita [thous. PLN].

Table 2 presents the most important parameters of waste management indicators for voivodships in 2019.

The uniform preference postulate was conducted for the examined indicators (formula 1), for which the following indicators (numbers) were classified as destimulants (subjective assessment): 1, 4, 6, 8 and 9, nominants were not included among the analysed indicators.

Based on the findings presented in table 2 , it is noticeable that the best levels of waste management indicators, in accordance with $S$ or D variable, were recorded twice for the following voivodships: Małopolskie (this result was influenced by indicators No. 2-3), Lubelskie (indicators No. 5, 8), Mazowieckie (indicators No. 6-7).

For the purpose of further research, the normalisation of waste management indicators (formula 2) was conducted, i.e. the values of indicators were removed, and the order of magnitude was unified to allow comparisons. 


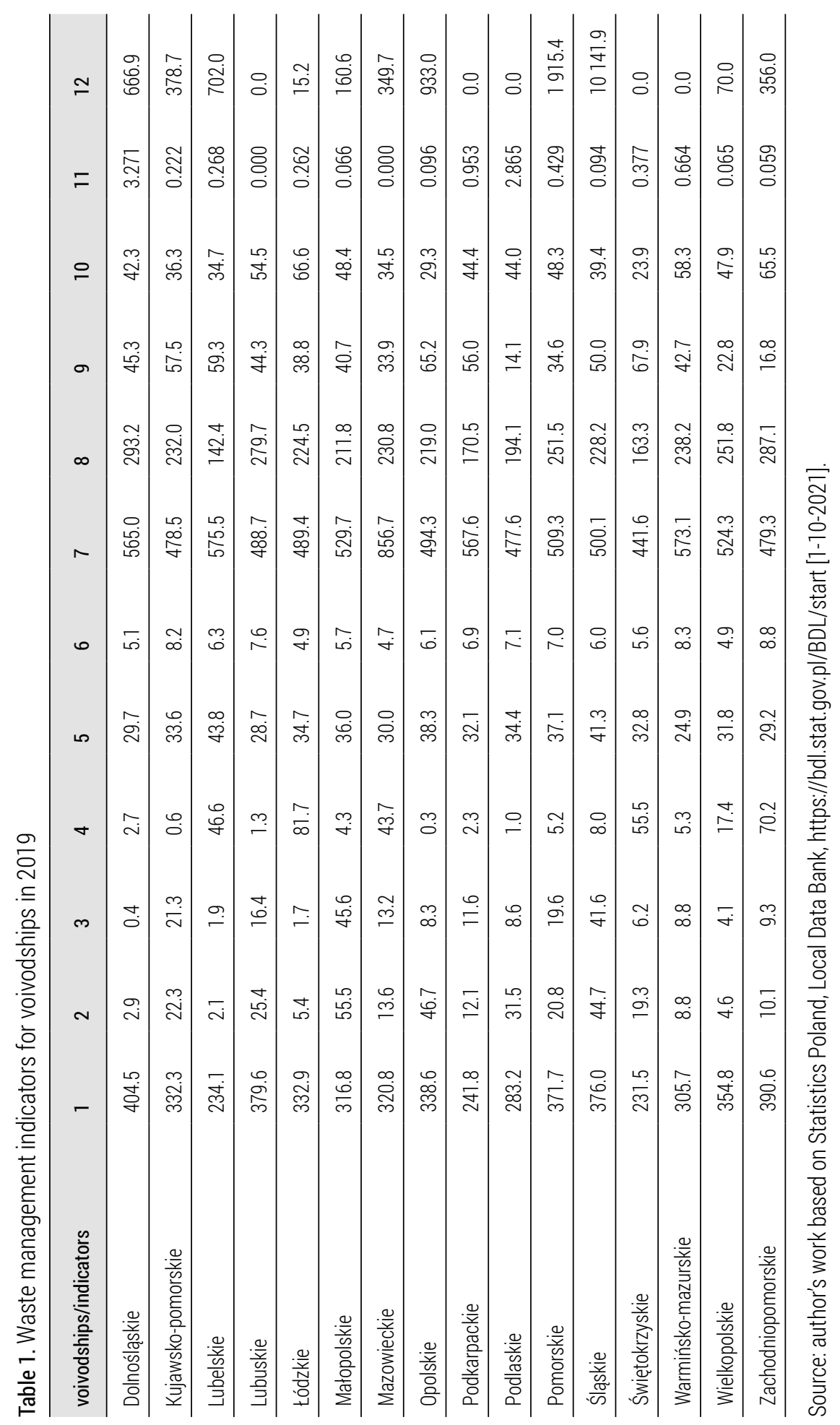


Table 2. The most important information for waste management indicators in the voivodships for 2019

\begin{tabular}{llllll}
\hline Indicators & $\begin{array}{l}\text { Arithmetic } \\
\text { mean }\end{array}$ & $\begin{array}{l}\text { Standard } \\
\text { deviation }\end{array}$ & $\begin{array}{l}\text { Nature of variables: } \\
\text { S-stimulant D-destimulant }\end{array}$ & $\begin{array}{l}\text { Levels max for } \\
\text { S and min for D }\end{array}$ & $\begin{array}{l}\text { Country with the the best level } \\
\text { according to S or D variable }\end{array}$ \\
\hline 1 & 0.73 & 0.14 & D & 231.5 & świętokrzyskie \\
\hline 2 & 20.36 & 16.63 & S & 316.8 & małopolskie \\
\hline 3 & 13.67 & 13.19 & S & 316.8 & małopolskie \\
\hline 4 & 0.17 & 0.27 & D & 338.6 & opolskie \\
\hline 5 & 33.65 & 4.89 & S & 234.1 & lubelskie \\
\hline 6 & 0.76 & 0.15 & D & 320.8 & mazowieckie \\
\hline 7 & 534.42 & 94.79 & S & 856.73 & mazowieckie \\
\hline 8 & 0.65 & 0.14 & D & 142.4 & lubelskie \\
\hline 9 & 0.40 & 0.23 & D & 14.1 & podlaskie \\
\hline 10 & 44.89 & 12.13 & S & 66.6 & tódzkie \\
\hline 11 & 0.61 & 1.00 & S & 3.271 & dolnośląskie \\
\hline 12 & 980.59 & $2,494.97$ & S & $10,141.9$ & śląskie \\
\hline
\end{tabular}

Source: author's work based on Statistics Poland, Local Data Bank, https://bdl.stat.gov.pl/BDL/start [1-10-2021].

Finally, linear ordering taking the form of synthetic development measure was performed (SDM) (table 3).

Table 3. Synthetic development measure (SDM) for the voivodship level

\begin{tabular}{llllll}
\hline $\begin{array}{l}\text { Voivodship } \\
\text { ranking }\end{array}$ & Voivodship & SDM & $\begin{array}{l}\text { Voivodship } \\
\text { ranking }\end{array}$ & Voivodship & SDM \\
\hline 1 & Śląskie & 0,47 & 9 & Pomorskie & -0.08 \\
\hline 2 & Podlaskie & 0,45 & 10 & Świętokrzyskie & -0.13 \\
\hline 3 & Małopolskie & 0,36 & 11 & Dolnośląskie & -0.17 \\
\hline 4 & Lubelskie & 0,17 & 12 & Wielkopolskie & -0.190 \\
\hline 5 & Opolskie & 0,16 & 13 & Kujawsko-pomorskie & -0.191 \\
\hline 6 & Mazowieckie & 0,10 & 14 & Zachodniopomorskie & -0.319 \\
\hline 7 & Podkarpackie & 0,08 & 15 & Warmińsko-mazurskie & -0.321 \\
\hline 8 & Łódzkie & $-0,07$ & 16 & Lubuskie & -0.34 \\
\hline
\end{tabular}

Source: own compilation. 
SMD results indicated that the highest level of waste management implementation was recorded in Śląskie Voivodship, presenting the highest level of "Expenditure on fixed assets for recycling and the use of waste per capita" indicator. It significantly differed from the level of other voivodships and, thus, significantly influenced the outcome. Podlaskie Voivodeship (ranked as the second) slightly differed from Śląskie Voivodship, which resulted from the dominant influence of the best level in the share of waste deposited in landfills as mixed waste (Podlaskie deposits the lowest volume of mixed waste in landfills). In turn, the lowest level of waste management implementation was recorded in Lubuskie Voivodeship, which presented the worst levels of indicators No. 11 and 12 and unfavourable levels of indicators No. 5 and 8. Lubuskie recorded the lowest overall expenditure on waste management (including no expenditure on fixed assets for waste management recycling) (Statistics Poland, 2020, p.18).

\section{Conclusions}

Based on the conducted comparative analysis for voivodships in accordance with waste management, the following conclusions can be formulated:

- no ranking was performed in the analysed set of indicators; however, there is a need for such ranking in terms of waste management importance being part of reverse logistics. As a result, among the analysed indicators, the ones related to the recovery and recycling processes should be assigned higher weights compared to others;

- directions of waste management activities, uniform for voivodships, in particular municipal waste management, should be identified;

- marshal's offices are not capable of balancing the processing capacity of municipal installations because ensuring the volume of waste for a full load of the installation will depend on the price for receiving waste, as well as the criterion of quality and efficiency of a given installation performance;

- an insufficient number of installations for waste recycling and incineration (waste incineration plants).

\section{References}

Act of December 14, 2012 on Waste (Journal of Laws 2021, item 779).

Act of September 13, 1996 on Maintaining Cleanliness and Order in Municipalities (Journal of Laws 2021, item 888).

Daniel, V., Guide, R., Luk, Jr., Van Wassenhove, N., 2009. OR FORUM - The Evolution of Closed-Loop Supply Chain Research. Operations Research, Vol. 57, No. 1, 10-18, https://doi.org/10.1287/opre.1080.0628. 
de Brito, M.P., Dekker, R., 2003. A Framework for Reverse Logistics. in: R. Dekker, M. Fleischmann, K. Inderfurth, L. van Wassenhove (Ed.), Reverse Logistics: Quantitative Models for Closed-Loop Supply Chains. Springer, Berlin, 3-27.

EU, 2018. Directive 1999/31/EC on the landfill of waste, L. 850.

EU, 2018. Directive 2000/53/EC on end-of-life vehicles, 2006/66/EC on batteries and accumulators and waste batteries and accumulators, and 2012/19/EU on waste electrical and electronic equipment, L. 849.

EU, 2018. Directive 2008/98/EC on waste, L. 851.

EU, 2018. Directive 94/62/EC on packaging and packaging waste, L. 852.

Fishbein, B.K., 1994. Germany, garbage and the green dot: challenging the throwaway society. Inform New York.

Gatnar, E., Walesiak, M., (eds.), 2004. Metody statystycznej analizy wielowymiarowej $\mathrm{w}$ badaniach marketingowych, Wydawnictwo Akademii Ekonomicznej we Wrocławiu, Wrocław.

Ginter, P., Starling M, 1978. Reverse distribution channels for recycling. California Management Review, vol. 20, no 3, 72-81.

Grabiński, T., 1984. Wielowymiarowa analiza porównawcza w badaniach dynamiki zjawisk ekonomicznych. Zeszyty Naukowe AE w Krakowie, Seria specjalna monografie nr 61, Kraków.

Grant, D. B., Wong, Ch. Y., Trautrims, A., 2017. Sustainable logistics and supply chain management: principles and practices for sustainable operations and management. Kogan Page Publishers.

Guiltinan, J., Nwokoye, N., 1975. Reverse channels for recycling: an analysis for alternatives and public Policy implications. New marketing for social and economic Progress, Combined Proceedings. American Marketing Association.

Hawks, K., 2006. What is Reverse Logistics? Reverse Logistics Magazine, Winter/ Spring.

Jajuga, K., Walesiak, M., 2000. Standardisation of data set under different measurement scales, In: R. Decker, W. Gaul (Eds.), Classification and information processing AT the turn of the millennium, Springer-Verlag, Berlin, Heidelberg.

Lambert, D.M., Stock, J.R., Ellram, L.M., 2000. Logistics, Praha, Computer Press.

Mesjasz-Lech, A., 2019. Reverse logistics of municipal solid waste - towards zero waste cities. Transportation Research Procedia 39, Vol.pp. 320-332, doi:10.1016/ j.trpro.2019.06.034.

Pluta, W., 1986. Wielowymiarowa analiza porównawcza w modelowaniu ekonometrycznym. Państwowe Wydawnictwo Naukowe, Warszawa.

Pociecha, J., Podolec, B., Sokołowski, A., Zając, K., 1988. Metody taksonomiczne w badaniach społeczno-ekonomicznych. Państwowe Wydawnictwo Naukowe, Warszawa.

Regulation of the Minister of the Environment of July 1, 2015 on the method and form of drawing up a voivodship waste management plan and an investment plan template (Journal of Laws 2015, item 1016).

Resolution No. 88 of the Council of Ministers of July 1, 2016 on the National Waste Management Plan 2022 (Monitor Polski 2016, item 784).

Rogers, D.S., Tibben-Lembke, R.S., 1998. Going backwards: Reverse Logistics Trends and Practices. University of Nevada, Center for Logistics Management, Reverse Logistics Executive Council, Pittsburgh. 
Rogers, D.S., Tibben-Lembke, R.S., 2001. An examination of reverse logistics practices. Journal of Business Logistics, 22(2), 129-148.

Statistics Poland, 2020. Ekonomiczne aspekty ochrony środowiska 2020, Warsaw.

Statistics Poland, Local Data Bank, https://bdl.stat.gov.pl/BDL/start [1-10-2021].

Szołtysek, J. 2009. Logistyka zwrotna. Instytut Logistyki i Magazynowania, Poznań.

Thierry, M., Salomon, M., Van-Nunen, J., Van Wassenhove, L., 1995. Strategic issues in product recovery management. California Management Review, 37(2), p. 114134.

Trebilcock, B., 2002. The seven deadly sins of reverse logistics. Logistics Management, Vol. 41 No. 6, 31-45.

Wadhwa, S., Madaan, J., Chan, F.T.S., 2009. Flexible Desicion Modeling of Reverse Logistics System: A Value Adding MCDM Aproach for Alternative Selection. „Robotics and Computer-Integrated Manufacturing. Vol. 25, Issue 2, 462.

Walesiak M., 1988. Skale pomiaru cech (w ujęciu zwężonym) a zganienie wyboru postaci analitycznej syntetycznych mierników rozwoju. Prace Naukowe AE we Wrocławiu nr 447, Wrocław.

Walesiak, M., 1993. Statystyczna analiza wielowymiarowa w badaniach marketingowych. Prace Naukowe AE we Wrocławiu nr 654, Seria Monografie i Opracowania $\mathrm{nr}$ 101, Wrocław.

Walesiak, M., 2006. Uogólniona miara odległości w statystycznej analizie wielowymiarowej. Wydawnictwo Akademii Ekonomicznej we Wrocławiu, Wrocław.

Walesiak, M., Gatnar, E., 2009. Statystyczna analiza danych z wykorzystaniem programu R. Państwowe Wydawnictwo Naukowe, Warszawa.

Zeliaś, A., 1989. Metody taksonomii numerycznej w modelowaniu zjawisk społeczno-gospodarczych. Państwowe Wydawnictwo Naukowe, Warszawa.

Zielińska, A., 2019. Comparative Analysis of Circular Economy Implementation in Poland and other European Union Countries. Journal of International Studies, 12(4), 337-347, doi:10.14254/2071-8330.2019/12-4/22.

Zielińska, A., 2020. A comparative analysis of reverse logistics implementation for waste management in Poland and other European Union countries. Journal of International Studies, 13(4), 171-183. doi:10.14254/2071-8330.2020/13-4/12.

Zielińska, A., Prudzienica, M., Mukhtar, E., Mukhtarova, K., 2016. The examples of reverse logistics application in inter-sector partnerships - good practices. Journal of International Studies, Vol. 9, No 3, 207-214, DOI: 10.14254/2071-8330. 2016/9-3/22.

Zielińska, A., Sej-Kolasa, M., 2004. Excel w statystyce, materiały do ćwiczeń, Wydawnictwo Akademii Ekonomicznej im. Oskara Langego we Wrocławiu, Wrocław. 